\title{
The Effect of Ownership Structure and Leverage Towards Dividend Policy and Corporate Values
}

\author{
MG Wi Endang ${ }^{\mathrm{a}}$, Suhadak ${ }^{\mathrm{b}}$, Mohammad Saifi ${ }^{\mathrm{b}}$ and Nila Firdausi ${ }^{\mathrm{b}} *$ \\ ${ }^{a}$ Business Administration Doctoral Program, Faculty of Administrative Sciences, University of Brawijaya, Malang Indonesia \\ ${ }^{b}$ Faculty of Administration Science, University of Brawijaya
}

\section{ARTICLE INFORMATION}

Article history:

Data submission : 01 September 2019

$1^{\text {st }}$ revision: 01 January 2020

Accepted: 10 January 2020

Available online: 01 February 2020

Keywords: ownership structure, leverage, dividend policy, firm value

\begin{abstract}
Every company (particularly the company's shareholders) always expects to have high company value. Various mechanisms are used by company managers to create corporate value. The mechanism can be through the structure of ownership, leverage, and dividend policy. Previous studies that have discussed the effect of ownership structure and leverage variables on dividend policy and corporate value provide different research results. This study aims to obtain empirical evidence of the effect of ownership structure and leverage on dividend policy and firm value, on manufacturing companies listed on the Indonesia Stock Exchange in the 20122016 period. The population of this study is all manufacturing companies listed on the Indonesia Stock Exchange that provide periodic financial statements from 2012 to 2016 (145 companies). The population that met the criteria to sampled was 28 companies. The research method used in this research is Warp-PLS. The results showed as follows: (1) The effect of ownership structure on dividend policy was negative and not significant; (2) The effect of ownership structure on firm value was negative and significant; (3) The leverage on dividend policy was negative and significant; (4) The leverage on the company value was negative and weak significant correlation; (5) The effect of the dividend policy on corporate value was negative and weak significant correlation.
\end{abstract}

2020 FIA UB. All rights reserved.

\section{Introduction}

The main goal of a company is increasing the company's value by increasing the prosperity of the owner or shareholder. Roseff's (1982) study of dividend policy and insider ownership is a tool to reduce agency costs. Easterbrook (1984) by adding monitoring companies prefer paying payout. Previous research that discusses the effect of ownership structure variables on dividend policy still gives different results. Research from Schooley and Barney (1994) found significant adverse results. Whereas McConnell and Serveas (1990) found a significant positive effect.

According to Jensen and Meckling (1976), agency problems occur due to the principle of separation of functions between managerial and company stock ownership. Jensen and Meckling (1976) found that there is a positive relationship between managerial stock ownership and firm value. The higher ownership of institutional shares causes the institution to control the decisions that managers will make. The effect of ownership structure variables on firm value finds different research results. Consistent research by Cho (1998), found a significant positive effect, whereas Chen et al. (2008) found a significant negative effect.

Companies that use high leverage would have to reduce or not pay dividends. The effect of leverage on dividend policy finds different results, consistent research from Asad and Yousaf (2014) found evidence of significant negative influence, while research by Easterbrook (1984), Strebulaev and Yang (2013) found a significant positive effect.

* Corresponding author. Tel.: + ; e-mail: wiendangfia@ub.ac.id 
Modigliani and Miller (1958) stated that debt is irrelevant to create corporate value. However, Modigliani and Miller (1963), with his Irrelevant Leverage Theory, have revised the previous statement. Modigliani and Miller stated that the use of debt by companies would able to create corporate value. This because there is tax protection against the use of leverage by companies. The consistent research by Akhtar et al. (2012) found a significant positive effect, which means that the use of high leverage will increase firm value. Ruland and Zhoa (2005) found a significant negative effect, whereas Enekwe et al. (2004) found no significant negative effect.

Miller's and Modigliani's (1961) stated that dividend policy does not affect the firm's value in a perfect capital market has led to criticism. Bhattacharyya (2007) developed the theory of Dividend Signaling Theory, assuming the existence of information asymmetry. Dividend policy is a signal of the company's prospects. Decreasing the number of dividend payments is terrible news. Moreover, conversely, an increase in dividend payments is considered good news. Garay and Gonzales (2007) found significant positive evidence, whereas Amidu (2007) found no significant negative results. Empirically, this research develops previous research, discuss and develop main concepts, explain ownership structure and leverage variables; there are dividend policies and company value.

\section{Theory}

The ownership structure is the proportion of total shares owned by members of the board of directors and supervisors, managerial, institutional, and public. The ownership structure variable has managerial ownership indicators, representing several shares owned by the company's management. Indicators of institutional ownership (Azzam, 2010) represent ownership by top management, individuals, public and private holding companies, public and private companies, public and private banks, insurance companies, and employee associations. Public ownership indicators (Azzam, 2010) are many shares held by the public.

Leverage (Enekwe et al., 2014) is a measurement of how companies use capital and debt to finance their assets. Indicators of Leverage are Debt Ratio, Dept. Equity Ratio. Dividend policy (Strebulaev, 2013) is compensation received by shareholders for a long time obtained on the company. Indicators of dividend policy are the dividend payout ratio, the dividend yield. Company value is an investor's perception of the level of success of a company in managing its resources. An indicator of company value is Tobin's $Q$,

The research hypothesis is as follows:

H1: Ownership structure affects dividend policy.

$\mathrm{H} 2$ : Ownership structure affects company value.

H3: Leverage affects the dividend policy.
H4: Leverage affects the value of the company. H5: Dividend policy affects the company supply.

\section{Research Method}

The type of data used in this study is secondary data in the form of time-series data (data collected in chronological order) and cross-section data. The data was obtained from the Indonesia Stock Exchange and published through the Indonesia Stock Exchange in 2012-2016.

Table 1. Variables, indicators, data sources and formula

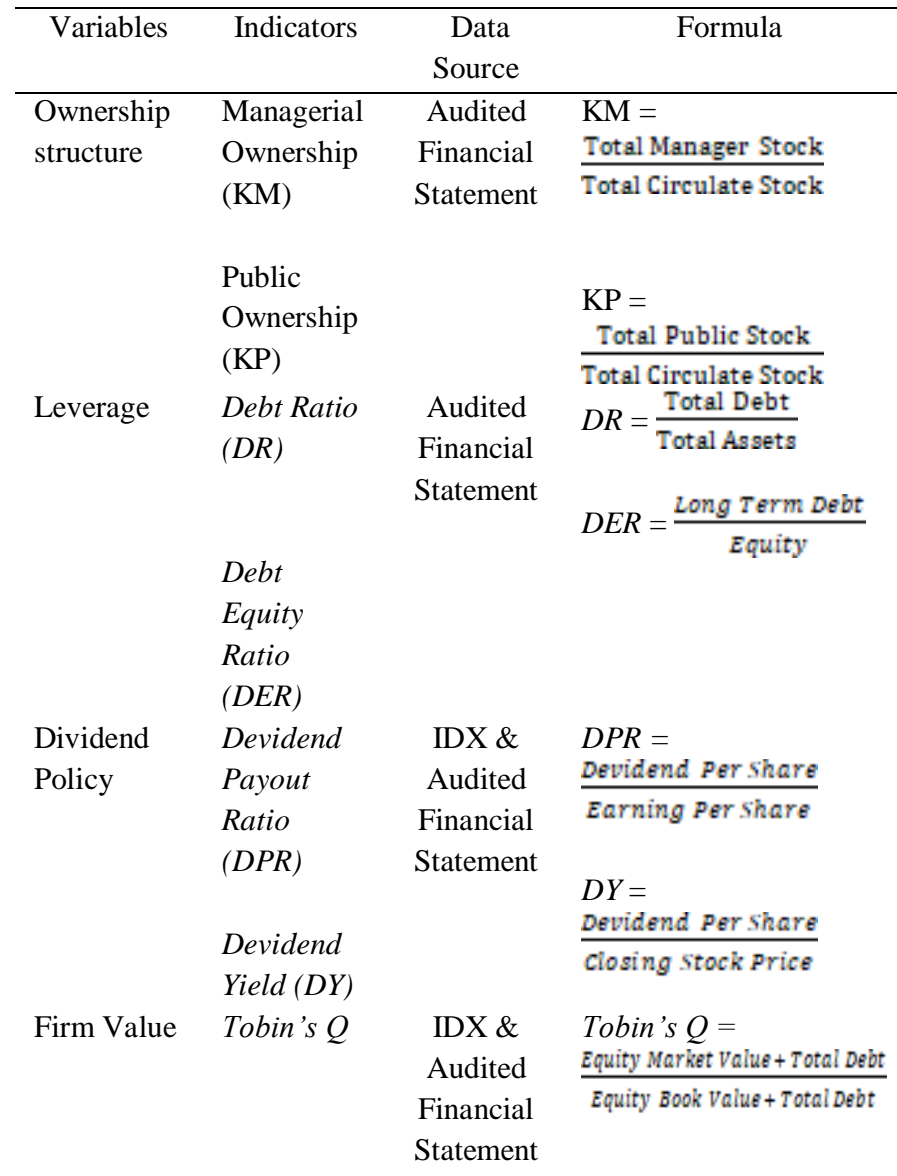

The population in this study are all manufacturing companies listed on the Indonesia Stock Exchange and provide periodic financial statements from 2012 to 2016 consisting of 19 industrial sub-groups totaling 145 companies. The sampling used was purposive sampling and based on judgment sampling. Samples taken from populations that meet the criteria for publishing financial statements are continuously reduced by 16 , minus 59, which presents profit and loss statements with profit and loss, minus 42 companies that distribute dividends, so the research sample is 28 companies. Table 1 presents data sources and formulas used in this study.

Data analysis methods used include financial ratio analysis, descriptive statistical analysis, and inferential statistical analysis. Inferential statistical analysis in this study used the Warp-PLS analysis. Warp-PLS is used 
based on the research concept model as a multiinfluence and tiered influence. Besides, the variables analyzed in this study are latent with a formative indicator model. The model of influence between variables in this study, described by the equation system as follows:

$$
\begin{aligned}
& Y_{1}=a_{1}+b_{1} X_{1}+b_{2} X_{2}+e_{1} \\
& Y_{2}=a_{2}+b_{3} X_{1}+b_{4} X_{2}+b_{5} Y_{1}+e_{2} \\
& \text { Where: } \\
& \mathrm{X}_{1} \quad \text { :Ownership structure } \\
& \mathrm{X}_{2} \text { : Leverage } \\
& \mathrm{Y}_{1} \quad \text { :Dividend Policy } \\
& \mathrm{Y}_{2} \text { : Firm Value }
\end{aligned}
$$

Indicator Weights Exploration. Indicator weight describes the strengths and weaknesses of the indicators (dimensions) as a measure of variables. Dimensions (indicators) with large factor weight values indicate these dimensions (indicators) have a strong ability to reflect variables. The dimension (indicator) with the most significant factor weight value is the most robust (dominant) as a measure of the relevant variable. Positive or negative signs indicate the direction, as found in the path coefficient (regression). The results of the factor weight values presented in Table 2.

Table 2. Indicator weight for variable of ownership structure, leverage, dividend policy, and firm value.

\begin{tabular}{lcc}
\hline \multicolumn{1}{c}{ Indicators } & weight & p-value \\
\hline Ownership structure & & \\
KM & 0,670 & $<0,001$ \\
KP & 0,670 & $<0,001$ \\
Leverage & & \\
DR & 0,518 & $<0.001$ \\
DER & 0,518 & $<0.001$ \\
Dividend policy & & \\
DPR & 0,634 & $<0,001$ \\
DY & 0,634 & $<0,001$ \\
Firm value & & \\
Tobin's Q & 1,000 & $<0,001$ \\
\hline
\end{tabular}

The results of the analysis show that all indicators are significant as a measure of the variable Structure of Ownership, Leverage, Dividend Policy, and Firm Value where all indicators and each variable have a balanced weight as forming the structure of Ownership Structure, Leverage, Dividend Policy, and Firm Value.

\section{Results}

The results of hypothesis testing can be seen in the following figure 1 . The results of the analysis of the effect of ownership structure on dividend policy obtained a path coefficient of -0.089 and $\mathrm{p}$-value $=$ 0.143 . The path coefficient marked negative indicates that greater share ownership will result in a decrease in the number of dividend payments. This study is consistent with the research of Azzam (2010) as well as
Schooley and Barney (1994), but do not support the research of Short et al. (2002) whose results were significantly positive.

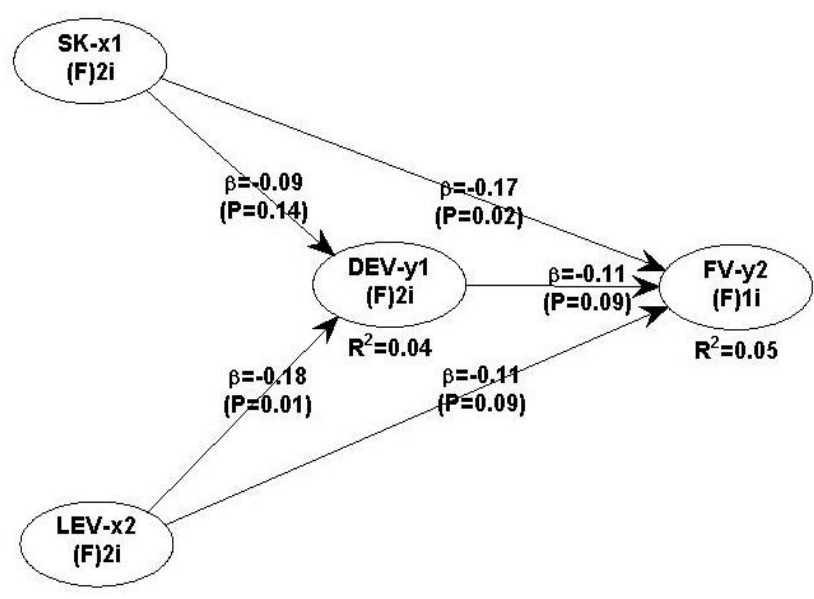

Figure 1. Conceptual framework

Table 3 . The results of hypothesis testing

\begin{tabular}{llcc}
\hline \multicolumn{1}{c}{$\begin{array}{c}\text { Independent } \\
\text { variables }\end{array}$} & $\begin{array}{c}\text { Dependent } \\
\text { variables }\end{array}$ & $\begin{array}{c}\text { path } \\
\text { coefficient }\end{array}$ & p-value \\
\hline $\begin{array}{l}\text { Ownership } \\
\text { Structure }\end{array}$ & Dividend Policy & -0.089 & 0.143 \\
$\begin{array}{l}\text { Ownership } \\
\text { Structure }\end{array}$ & Company Value & -0.167 & 0.021 \\
Leverage & Dividend Policy & -0.179 & 0.015 \\
Leverage & Dividend Policy & -0.110 & 0.090 \\
Dividend policy & Company Value & -0.110 & 0.092 \\
\hline
\end{tabular}

\section{Discussion and Conclusion}

The results of the analysis of the effect of ownership structure on the value of change obtained by the path coefficient of -0.167 and $p$-value $=0.021$. The path coefficient marked negative indicates that the greater share ownership will cause the company's value to fall. This study is consistent with the research of Chen et al. (2008) but does not support the research of Cho et al. (1998) whose results were significantly positive.

The results of the analysis of the influence of leverage on dividend policy obtained a path coefficient of -0.179 and $p$-value $=0.015$. The path coefficient marked negative indicates that the higher use of leverage will lead to a decrease in the company's ability to pay dividends. This research is consistent with the research of Asad and Yousaf (2014), but it does not support the research of Strebulaev and Yang (2013) whose results are significantly positive.

The results of the analysis of the influence of leverage on the company's value obtained by the path coefficient of -0.111 and $p$-value $=0.090$. The path coefficient marked negative indicates that the higher the use of leverage can reduce the value of the company. This study is consistent with the research of Ruland and 
Zhou (2005) whose results were significantly positive and the study of Enekwe et al. (2004) whose results were negative and not significant.

The results of the analysis of the effect of dividend policy on company value obtained path coefficient of 0.110 and $p$-value $=0.092$. The path coefficient marked negative indicates that the higher the company's ability to pay dividends will cause a decrease in the value of the company. This study does not support the research of Garay and Gonzales (2007) whose results were significantly positive, and the Amidu research (2007) whose results were negative and not significant.

This study concludes (1) The effect of ownership structure on dividend policy is negative and insignificant, (2) The effect of ownership structure on firm value is significantly negative, (3) The effect of Leverage on dividend policy is negative significant, (4) Effect of Leverage on firm value is significant negative, (5) The effect of dividend policy on firm value is significant.

\section{References}

Amidu, M. (2007). How does dividend policy affect performance of the firm on Ghana stock exchange? Investment Management and Financial Innovations, 4(2)3-7.

Asad. M., \& Yousaf, S. (2014). Impact of leverage on dividend payment behavior of Pakistani manufacturing firms. International Journal of Innovation and Applied Studies, 6(2)3-10.

Azzam, I. (2010). The impact of institutional ownership and dividend policy on stock return and volatility: evidence from Egypt. International Journal of Business, 15 (4).

Bhattacharyya, N. (2007). Dividend policy: a review. Managerial Finance, 1(2)5-10.

Chen, J., Blenman, L., \& Chen, D-Hsin. (2008). Does institutional ownership create value? The New Zealand case. Quarterly Journal of Finance and Accounting, 47.

Cho, M. H. (1998). Ownership structure, investment, and the corporate value: an empirical analysis. Journal of financial economics, 47(1), 103-121.

Easterbrook, F. (1984). Two agency cost explanations of dividends. American Economic Review 74(1), 650-659.

Enekwe, C.I., Agu, C.I., \& Eziedo, K.N. (2014). The effect of financial leverage on financial performance: evidence of quoted pharmaceutical companies in Nigeria. IOSR Journal of Economics and Finance (IOSR-JEF). 5(3), 17-25.

Garay, U. \& Gonzales, M. (2008). Corporate governance and fim value: the case of Venezuela. Journal Compilation, 16(1)3-7.

Jensen, M. C. \& Meckley, W.H. (1976). Theory of the firm: managerial behavior, agency costs, and ownership structure. Journal of Financial Economics 3(1), 305-360.

McConnell, J.J., \& Serveas. H. (1990). Additional evidence on equity ownership and corporate value. Journal of Financial Economics 27 (2), 595-612.

Miller, M.H., \& Modigliani, F. (1961). Dividend policy, growth, and the valuation of shares. Journal of Business, 34(1) 411-433.

Modigliani, F. \& Miller, M.H. (1958). The cost of capital, corporation finance and the theory of investment. The American Economic Review, 48(3) 261-297.

Rozeff, M. (1982). Growth, beta, and agency costs as determinants of dividend payout ratios. Journal of Financial Research, 5(1) 249-259.

Ruland, W., \& Zhou, P. (2005). Debt, diversification, and valuation. Review of Quantitative Finance and Accounting, 25(3), 277-291.

Strebulaev, I.A. \& Yang, B. (2013). The mystery of zero-leverage firm. Journal of Financial Economics, 109(1), 1-23. 